\title{
Ultrasonic method of Biodiesel production from Palm kernel
}

\author{
O.K. Onanuga and J . O. Coker*
}

Department of Science Laboratory Technology, Lagos State Polytechnic, Ikorodu, Lagos, NIGERIA

*Corresponding author: E-mail: jocoker20@yahoo.com

Received: 0 ctober 17, 2012; Revised received:December 14, 2012; Accepted: J anuay 5, 2013

\begin{abstract}
Biodiesel is a clean burning alternative fuel derived from chemical reactors produced from palm kernel oil, is currently spreading like a wind dust in the air. It is considered as the fuel for the future without rise in global warming. It has advantages over the fossil fuel diesel as sustainability (renewable resources), ease of production, and availability of raw materials. The study examines the biodiesel produced through transesterification of palm kernel oil ( $1 \%$ fatty acid) with methanol using granulated sodium hydroxide as catalyst through ultrasonic method. The palm kernel oil biodiesel produced was characterized as alternative diesel fuel through standard tests (ASTM) for basic fuel properties such as viscosity, cloud point, pour point, flash point and specific gravity as well as economical feasibility for Nigeria. The result showed that $875 \mathrm{~g}$ of palm kernel oil (1\% fatty acid) with $175 \mathrm{~g}$ of methanol using $13 \mathrm{~g}$ of sodium hydroxide (granulated) subjected to ultrasonic method for 1 hour through transesterification process produced $96.23 \%$ of biodiesel and $16.89 \%$ of glycerol plus high excess methanol was allowed to settle for 6 hours. Two layers were observed containing unwashed biodiesel at the top and darker layers of glycerin. After washing the biodiesel with warm water, the cleaned, biodiesel was dried by heat to remove the moisture from and allowed to settle down. A bright colour biodiesel was obtained which was within the international standard for biodiesel fuel.
\end{abstract}

Keywords: ASTM, Biodiesel, Diesel fuel, Transesterification, Ultrasonic method

\section{INTRODUCTION}

Biodiesel is an alternative diesel fuel produced from renewable biological sources like vegetable oil and animal fat of very low fatty acid for diesel engine. This is done by reacting, the oil (triglycerides) with an alcohol (mainly methanol or ethanol ) in the presence of a suitable alkali or acid catalyst yielding straight chain molecules of methyl or ethyl esters (Khalisanni et al., 2008 and Younis et al., 2009). It is highly favoured as alternative to fossil fuel diesel because it is renewable and environmentally friendly (Zhang et al., 2003). Over a century ago, Rudolf Diesel tested vegetable oil as fuel for engines, but the use was abandoned with the advent of petroleum diesel. However, the supply of these non-renewable energy sources is threatening to run out in a foreseen able future (Sambo, 1981 and Munack et al., 2001), and it was widely reported that not less than ten major oil fields from the 20 largest world oil producers are already experiencing decline in oil reserves. Published data also revealed a total of 29 major world oil producing countries already experiencing declining oil reserves (EIA, 2007 and Alamu et al., 2007). In comparison of Biodiesel to petroleum diesel fuel has distinct advantages which include its nontoxic-high biogradable and non-flammable characteristics (Bajpai and Tyagi, 2006). It gives less exhaust emissions, cleaner-burning alternative, improved biodegradability and high cetane rating which improve performance and emissions. Margaroni (1998), Ryan et al. (1982), Knothe and Steidley (2005), Krahl et al. (2005) stated that typical biodiesel produces about $65 \%$ less net carbon monoxide, $78 \%$ less carbon dioxide, $90 \%$ less sulphur dioxide and $50 \%$ less unburnt hydrocarbon emission. Due to the increasing global urgency to reduce dependence on fossil fuel diesel, Europe including Nigeria has been researching along that trend. The prospect of Biodiesel production in Nigeria is bright now, with a larger variety of oil crops planted in various parts of the country depending on the climatic conditions. The oil crops include; coconut palm (Cocus nucifera) and oil palm (Elaeis guineesis) in the South, while in the northern part there is soyabean (Glycine max), groundnut (Arachis hypogea), shea butter (Sesomum indicum). Nigeria is rated as one of the world producers of palm Kernel (vegetable oil) next to Malaysia, Indonesia and ahead of Cote d'ivore, Colombia, Thailand, Zaire and Equador. In addition, with the present drive on agricultural reforms by the Federal Government of Nigeria, the yields of oil crops are expected to increase significantly in the near future which implies, continuous availability of these renewable oils yield from the crops. Recently, with the increase in the price of fossil fuel (diesel) and the scarcity of the diesel cope with the negative environmental concerns (i.e global warming), there is need to focus on an alternative use of vegetable oils and their derivatives as an alternative Biodiesel fuel. 
Biodiesel has also been found to have relatively high heat value,high oxygen value and does not contribute to global warming due to its closed carbon cycle (Fukuda et al., 2001 and Demirbas, 2003). Krawczyk (1996); Connemann and Fischer (1998); Zhang et al. (2003) reported that approximately $70-95 \%$ of the total biodiesel production cost arises from the cost of the raw material; that is, vegetable oil or animal fats as a result of its direct competition with food. Therefore, the use of waste cooking oil and non edible oils such as castor oil, rubber seed oil ,jatropha oil ,citrus seed oil and sunflower oil are currently being considered by many researchers (Haque et al., 2009; Oghenejoboh et al., 2010; Agarry et al., 2010) for the full benefits of biodiesel production to be realized. For optimum performance of biodiesel for internal combustion engines, there may be needed to blend the biodiesel in various ratios with conventional petroleumbased diesel (Khan et al., 2000).

Until now lauric vegetable oil in Nigeria which had the highest fatty acid profile, composition (\% by weight) is under utilized as edible oil. In this study, the palm kernel oil biodiesel produced through transesterification of palm kernel oil with methanol (5:1) using granulated sodium hydroxide (catalyst) and expose to ultrasonic method was characterized as alternative diesel fuel through standard tests (ASTM) for basic fuel properties such as viscosity, cloud point, pour point and specific gravity.

\section{MATERIALS AND METHOD}

The vegetable oil (1\%fatty acid) was purchased at Ikorodu market, Lagos Nigeria. Methanol was used (99.5\% pure) as the alcohol, the catalyst was granulated sodium hydroxide $(\mathrm{NaOH})$, a dry and wet mill blender with a clear glass, electronic balance and scale, two funnels, pipette, measuring beakers; container, PET bottles, thermometers, a Bunsen burner, aluminum pot with cover, Pensky martens (flash point Tester), Gravity Hydrometer, viscous meter machine; petroleum fuel diesel. The pipette, measuring beakers, blender cup (reactor) and funnels were washed with methanol and allowed to dry before use. $875 \mathrm{~g}$ vegetable oil was measured out, warmed to $60^{\circ} \mathrm{C}$ to remove moisture from the oil and allowed to cool to the ambient temperature. $13 \mathrm{~g}$ of granulated sodium Hydroxide was gently dissolved inside $175 \mathrm{~g}$ of methanol in the catalyst pre-mix beaker and continuously stirred until it dissolves completely to form sodium methanol. The pre heated $875 \mathrm{~g}$ vegetable oil plus sodium methanol poured inside the blender with the blender lid tightly secured, the blender switched on intermittently for 3 occasions for the next one hour. The final liquid product was left to settle for several hours, preferably overnight to ensure complete separation. Two liquid phases were obtained; biodiesel (ester) and raw glycerin, the top biodiesel was separated by using a pipette funnel sipped gently from the blender into big ragolis plastic bottle containing warm water to wash away excess methanol. The unwashed biodiesel will float inside the warm water and agitate gently punctured underneath to remove excess methanol and catalyst from the ragolis bottle, washing of biodiesel continue until the underneath punctured water tested neutral using a litmus paper. The washed biodiesel collected poured inside a towel aluminum pot covered and heated until no sound was heard and was brought down from the fire to cool. It shows the water has been removed completely from the biodiesel. It was allowed to cool and a bright coloured biodiesel was observed. ASTM standard fuel tests were carried out to compare the control diesel (fossil fuel) with the produced biodiesel.

Bio-diesel fuel characterizations: ASTM standard fuel test were conducted on the Vegetable (PKO) biodiesel and low sulphur diesel of $0.3 \%$ rate max, with diesel index 47 and the colour was clear and bright purchased at Total filling station Odogunyan, Lagos State, Nigeria. Specific gravity and Viscosity measurements were carried out using the Hydrometer apparatus and Viscometer. The flash point measurement was carried out Pensky Mortens flash points testers, following ASTM standard. The biodiesel was analyzed for cloud and pour point using Baskeyl Setapoint cloud and pour point apparatus following ASTM standards respectively.

Fuel characteristics analysis: The produced PKO biodiesel and the Fossil fuel diesel, used as control over the biodiesel were analyzed at the NNPC laboratory/ Lagos State Polytechnic (Biochemistry) for basic fuel properties.

\section{RESULTS AND DISCUSSION}

The results on fuel characteristics analyses of bio-diesel produced from PKO (Vegetable) are given in Table 1. The raw PKO (vegetable) had viscosity of $32.40 \mathrm{~mm}^{2} / \mathrm{s}$ as reported earlier (Abigor et al., 2000, Alamu et al., 2007, Alamu et al., 2008). The PKO biodiesel viscosity obtained showed about $87 \%$ reduction. This will promote the biodiesel's fluidity in diesel engines. The results obtained over fossil fuel diesel were higher in terms of density $\left(860 \mathrm{~kg} / \mathrm{m}^{3}\right)$, pour point $\left(-15.0^{\circ} \mathrm{C}\right)$, cloud point $\left(8.0^{\circ} \mathrm{C}\right)$ and flash point $\left(98^{\circ} \mathrm{C}\right)$.

At $15.6{ }^{\circ} \mathrm{C}$, the specific gravity of PKO (vegetable) biodiesel was 1.01176 times more than that of petroleum diesel. The flash point of the produced bio-diesel satisfies the Nigeria National Petroleum Corporation (NNPC) standard which is the minimum $66^{\circ} \mathrm{C}$ for Diesel engine. The higher the temperature, the better the quality of the product but it should not be below $66^{\circ} \mathrm{C}$.

These values were also matched with international standards for biodiesel including EN14214 (Europe). The comparison made revealed good agreement as is evident 
Table 1. Fuel characteristics of bio-diesel produced from palm kernel oil (Vegetable).

\begin{tabular}{lccc}
\hline $\begin{array}{l}\text { Fuel characteristics } \\
\text { (Properties/parameters) }\end{array}$ & PK O biodiesel & Fossil fuel diesel & $\begin{array}{c}\text { E N 14214 Eur opean } \\
\text { biodiesel standard }\end{array}$ \\
\hline Specific gravity kg/m & & 850 & $860-900$ \\
Kinematic Viscosity @ $37.8^{\circ} \mathrm{C}\left(\mathrm{mm}^{2} / \mathrm{s}\right)$ & 860 & 4.5 & $3.50-5.00$ \\
Pour point $\left({ }^{\circ} \mathrm{C}\right)$ & 4.8 & -27.5 & \\
Cloud point $\left({ }^{\circ} \mathrm{C}\right)$ & 8.0 & 4.4 & $>66$ \\
Flash point & 98 & 72 & \\
\hline
\end{tabular}

from Table 1.

From the yield of Palm Kernel (Vegetable) biodiesel and fuel characterization of PKO biodiesel carried out, analyzed and compared with fossil fuel diesel under International Standards ( i.e ASTM -900 and EN14214). The transesterification process carried out using Palm Kernel oil/methanol ratio $(5: 1), 1.1 \% \mathrm{NaOH}$ (by total weight of mixture) at $60^{\circ} \mathrm{C}$ reaction temperature and 65 minutes reaction time yielded $842 \mathrm{~g}$ PKO biodiesel. The specific gravity of $\mathrm{PKO}$ biodiesel was $860 \mathrm{Kg} / \mathrm{m}^{3}$ against $850 \mathrm{Kg} / \mathrm{m}^{3}$ fossil fuel diesel. At $37.8^{\circ} \mathrm{C}$, the Viscosity of PKO biodiesel was $4.8 \mathrm{~mm}^{2} / \mathrm{s}$ of the fossil fuel diesel. Pour point $\left({ }^{\circ} \mathrm{C}\right)$ was $-15^{\circ} \mathrm{C}$ of $\mathrm{PKO}$ biodiesel against $-27.5^{\circ} \mathrm{C}$ of diesel cloud point $8^{\circ} \mathrm{C}$ and the flash point $98^{\circ} \mathrm{C}$ compared to $4.4^{\circ} \mathrm{C}$ and $72^{\circ} \mathrm{C}$ obtained for commercial grade and found very suitable substitute for conventional fossil fuel diesel. The yielded biodiesel produced can fuel a diesel engine.

\section{Conclusion}

Based on the results of this study, the following conclusions can be drawn: the ultrasonic method used in the production of clean Biodiesel as an alternate to convention fossil diesel reduce the transesterification reaction time to 24 hours when compared with chemical process of producing same Biodiesel for days. This method provide the properties and the characterization of Biodiesel which is within the limit of ASTM standard and Nigeria National Petroleum Corporation standard (NNPC).

\section{REFERENCES}

Abigor, R. D., Uadia, P. O., Foglia, T. A. Haas, M. J, Jones, K. C., Okpala, E., Obibuzor, U. and Bafor, M. E. (2000). Lipase-catalysed production of bio-diesel fuel from some Nigerian lauric oils. Biochemical Society Transactions, 28(6): $979-980$

Aderemi, B. O. and Hameed, B. O. (2010). Production of biodiesel from palm oil. Proceedings of Conference of Nigerian Society of C hemical E ngineers, 40: 135-143

Agarry, S. E., Ajani, A. O., Aworanti, A. O. and Solomon, B. O. (2010). 'Alkali-catalysed production of biodiesel fuel from Nigerian citrus seeds oil. Proceedings of Confer ence of Nigerian Society of C hemical E ngineers, 40: 145-154

Ahmad, M., Rashid, S., Khan, M. A., Zafar, M., Sultan, S. and Gulzar, S. (2009). Optimisation of base catalysed transesterification of peanut oil biodiesel. African J ournal of Biotechnology, 8 (3): 441-443

Ajav, E. A. and Akingbehin, A. O. (2002). A study of some fuel properties of local ethanol blended "with Diesel Fuel'. Agricultural Engineering International: the CIGR J ournal of Scientific Research and Development, Manuscript EE01003, Vol. IV

Alamu, O.J., Wxaheed, M.A, and Jekayinfa, S.O. (2007a). Alkali-catalysed laboratory production and testing of biodiesel fuel from Nigerian palm kernel oil. Agricultural Engineering International: the CIGR J ournal of Scientific Research and D evelopment..IX: EE 07009

Bajpai, D. and Tyagi, V. K. (2006). Biodiesel: source, production, composition, properties and its benefits. J 0 leo Sci., 55 (10): $487-488$

Connemann, J. and Fischer, J. (1998). Biodiesel in Europe 1998: Biodiesel processing technologies' Paper Presented at the International Liquid Biofuels Congress, Brazil

Demirbas, A. (2003).Biodiesel from vegetable oils via catalytic and non-catalytic supercritical alcohol transesterification and other Methods: A survey' in energy conversion and management, 44: 2093 - 2109

EIA. 2007. "Energy Information Administration. World Proved Reserves of Oil \& Natural Gas. Most Recent Estimates'.

Fukuda, H., Kando, A. and Noda, H. (2001). Biodiesel fuel production by transesterification of oils. J ournal of Bioscience and Bioengineering, 92: $405-410$

Haque, M. A., Islam, M. P., Hussain, M. D. and Khan, F. (2009). Physical, mechanical properties and oil content of selected indigenous seeds available for biodiesel production in Bangladesh. CIGR Ejournal, XI: 2- 4.

Khalisanni, K., Khalizani, K., Rohani, M. S. and Khalid, P. O. (2008). Analysis of waste cooking oil as raw material for biofuel production. Global J ournal of Environmental Research, 2 (2): 81-83

Khan, M. I., Chhetti, A. B. and Islam, M. R. (2000). Community based energy model: A novel approach in developing sustainable energy. Energy Sources, 69: 21 -23

Knothe, G. and Steidley, K.S. (2005). Kinematic viscosity of biodiesel fuel component and related compounds: Influence of compound structure and comparison to petrodiesel fuel components. F uel, 1059-1065.

Krahl, J., Munack, A., Schröder,O., Stein, H., Herbst, L. Kaufmann, A. and Bünger, J. (2005). Fuel design as constructional element with the example of biogenic and fossil diesel fuels. Agricultural Engineer ing International: the CIGR J ournal of Scientific Research and D evelopment. VII: EE 04008

Krawczyk, T. (1996) 'Biodiesel; in INFORM, 7 (8): 801 -805 
Margaroni, D. (1998). Fuel lubricity. Industrial Lubrication and Tribology. 50(3): 108-118.

Munack, A., Schroder,O., Krahl, J. and Bunger, J. (2001). Comparison of relevant exhaust gas emissions from biodiese and fossil diesel fuel. Agricultural Engineering International: the CIGR J. Sci. Res. Dev., 3(EE 01-001)

Oghenejoboh, K. M., Akhihiero, E. T. and Adiotomre, K. O. (2010). Viability of biofuel as alternative fuel in Nigeria's transport system. International J ournal of Engineering, 4 (3): 445-453

Ryan, T.W., Callahan,T.J. and Dodge, L.G. (1982). Characterization of vegetable oils for use as fuel in diesel engines, Proc. International C onf. on Plant Oils as F uels. A merican Society of Agricultural E ngineers. 4(82): 70-81.

Sambo, A.S. (1981). Renewable energy technology in Nigeria: resource availability and potential for application to agriculture. J . Agric. Technol., 3(1): 1-4.

Younis, M. N., Saeed, M. S., Khan, S, Furgan, M. U. and Saleem, M. (2009). Production and characterisation of biodiesel from waste and vegetable oil. J ournal of Q uality and Technology M anagement, 5 (1): 111-114

Zhang, Y., Dube, M.A., McLean, D.D., and Kates, M. (2003). Biodiesel production from waste cooking oil: 1 . Process design and technological assessment. Bioresour. Technol., 89:1. 